\title{
Criminological Aspect on Case of Prostitution around Poncol Station Semarang
}

\author{
Andri Aditya Wicaksono ${ }^{1} \otimes$, Yusuf Rizky Saefudin², Hafiz Ramadhan³, Rico Alfian \\ Pangestu ${ }^{4}$, Ridwan Arifin ${ }^{5}$ \\ 1, 2, 3, 4, 5 Faculty of Law, Universitas Negeri Semarang, Indonesia \\ andriadityaaa@gmail.com
}

\begin{abstract}
Prostitution is an anti-social sexual deviation because it violates the norms of decency, norms of decency, customary norms and religious norms. This prostitution occurs in society in the form carried out by a group or individual in an organized manner consisting of pimps, the purpose of getting wages or rewards from those who have used their services. there are two parties namely PSK (Commercial Sex Workers) and masher men as customers. In the Criminal Code (KUHP) only regulates pimps, not yet regulating PSK and its customers. This has an impact on the development of prostitution in people's lives. Prostitution is regulated in Article 296 and Article 506. There are various factors behind the occurrence of this prostitution, such as economic factors caused by economic pressures and life burdens, there are also social factors such as the social environment, and family factors due to divorce or family problems. This study aims to find out what factors underlie the phenomenon of a CSW and analyze based on the perspective of criminological law. This research is located at Semarang Poncol Station on Jalan Imam Bonjol Semarang. This research uses an empirical and qualitative juridical approach. The results of the research and discussion show that the author obtained, among others, can be explained through the formulation that we discussed, namely: The characteristics that exist in the perpetrators of street prostitution, the impact on prostitution, technicalities in transactions between customers and prostitutes, and theories justify the existence of deviations in prostitution.
\end{abstract}

Keywords: prostitution, criminology, commercial sex workers, Poncol station

\section{Introduction}

Prostitution is a social phenomenon which in practice not only discusses the sexual relations between victims and perpetrators, reveals the dark side of humans, but also studies how they covertly enjoy and utilize the existence of prostitution. Etymologically the word prostitution from the Latin word "pro-stituere" means to allow oneself to commit adultery, commit prostitution, sexual abuse and agitation. Whereas the word "prostitute" is termed as WTS or Wanita Tuna Susila. Someone who sells sexual services is called WTS, which is now often referred to as Commercial Sex Workers (CSWs) (Siregar, 2015). Prostitution can also be interpreted as a job that is surrendering or selling services to the public to perform sexual acts in exchange for compensation in accordance with what was previously promised by hanging off the roadside or in a localization area. There are so many in this country doing this work with different backgrounds.

In Indonesia, prostitution is considered as a crime where in its scope there is a violation of moral values, moral values, and is an act against the 
law. In this case, the subject of prostitution is generally a woman. There are so many cases of female prostitution that are the main target of pimps (pimps) or masher men so that women become victims. Women are often tricked by the lure of money or easy jobs with high salaries, but in the end, they fall into a vicious circle. However, there are also other factors that women volunteer to make themselves as perpetrators or victims in the world of prostitution. Small examples of economic factors or factors of household problems that cause a woman to divorce her husband, solitude makes a woman clogged and then participate in the world of prostitution. The invitation factor for friends can also affect a person's mind or because he himself doesn't know what to do to fulfill his life's needs.

Prostitution is a practice of satisfying lust that is carried out by individuals or groups of people as commercial work. In prostitution there are elements contained, namely transactions, infidelity, emotional indifference, and livelihood. When viewed from the prevailing norms and developing in the community whether in terms of customary law, religious law, or normative law of prostitution and prostitution is an act that deviates and acts that can not be justified. But even though it is seen as deviant and the evil deeds of prostitutes (prostitutes), and customers (clients) cannot be convicted.

In normative law enforcement, article 296 states: "Anyone who intentionally connects or facilitates obscene acts by others with others, and makes them livelihoods or customs, is threatened with a maximum imprisonment of one year and four months or a maximum of one thousand rupiahs in fines" . Article 506 states: "Anyone who benefits from the obscene acts of a woman and makes a living, is threatened with a maximum sentence of one year" (Moeljatno, 2008).

The existence of laws governing prostitution, article 296 and article 506 of the Criminal Code can only criminalize the pimp only because it only regulates who is the liaison and cause of a woman and a man can commit adultery. The regulation does not regulate in detail the perpetrators and victims in the practice of prostitution.

The number of brothels in cities is caused by the fact that in normative law enforcement there is no specific regulation on prostitution. Indeed, our normative law is the Criminal Law Act of Westerners who do not really take care of private life, especially if the perpetrators or victims of prostitution do so voluntarily or forced with economic conditions that squeeze the necessities of life. Things like this that make prostitution as allowed or given permission to stay alive and develop in the community. But there is also the role of the community so that prostitution remains in their environment. Like letting them prostitutes and customers do the action to be indifferent or support their activities. People sometimes are not too concerned with moral values or moral values that should be upheld in their environment. Their own background or environment can also determine why people can act in this way.

In practice, prostitution itself in Indonesia is divided into two, namely:

1. Registered prostitution, where there is supervision from the police and cooperation with social services and health services to look after prostitutes. Those prostitutes are usually placed in a special localization place in a certain area, which then periodically they can check themselves into the health facility that has been provided to secure health and general conditions.

2. Unregistered prostitution, which in practice is carried out in disguise and wildly, both from person to person or from a group. Their actions and organization are not clearly organized. They can look for themselves, brokers, or calls.

There are separate obstacles if you want to eliminate prostitution itself, reasons for divorce, resignation to the situation, first become a victim and then even plunge into prostitution, and also the most recent is economic reasons. Economic reasons make the intention to eliminate prostitution more difficult because they prostitutes will question their fate to those who want to eliminate the job. Prostitution and prostitution that have become a habit in the community become a separate commodity for those who are accustomed to doing it. They consider the work to be limited to the use of goods and services. In addition to personal reasons that are inhibiting factors, there are also obstacles from their pimps who threaten victims not to go out of business. There are also networks that influence the difficulty of eliminating this prostitution business, such as social networks, prostitution business networks, the role, functions and marketing of pimps.

Social network is the result of an interaction relationship between one individual and another that causes an action to occur. In this case analyzing social networks wants to study the 
regularity of individuals and groups behaving rather than the regularity that they should do.

Prostitution business networks are inseparable from the activities of prostitution business people who then make prostitution a work that has a working system in it. The actors have their respective roles in running this business so that it can run well.

The role, function and marketing of pimps in their implementation governs the pattern of rules that connect one point to another, which then arises a bond between them, then creates laws to regulate the relationships they create. Marketing is done by pimps in the outline of connecting customers with prostitutes who carry out the work.

The existence of a system in such a way as to create its own structure in the business of prostitution, the aim is to protect and meet the needs of supply in accordance with demand. This promotion was carried out to introduce a new distribution.

Networks like this are just people who are indifferent to allowing this evil thing to happen. The community is not to pull them out of the network but instead to label them with a bad name, which in turn makes the residents even more inclined to carry out work in a pimp network and network or prostitute themselves. Things like this that make prostitution difficult to destroy.

We know that the rights of every person to his personal self cannot be contested, we also recognize how someone uses their sexual rights. But what does this mean for human rights if every day many women enter the world of prostitution. Prostitution is an act of violence that makes the last reason to fulfill their needs. As long as what becomes a problem a person is unable to meet his needs, then to eradicate prostitution down to its roots only becomes a wishful thinking. Providing education, socializing understanding of prostitution, fighting the dangers of prostitution and empowering productive women is a way to prevent or eliminate prostitution. Eliminating prostitution is a reason for creating jobs, eliminating the wage gap of women and men workers, and providing education without burdening their expenses. The point is that the work of prostitution and the prostitution business is the last reason they can take because they are resigned to the situation.

The problems discussed in this research and paper include:

1. What are the characteristics of commercial sex workers in the Poncol Station area?
2. What is someone's background as a CSW?

3. How is the technical PSK transaction in Poncol Station area?

4. What is the theory that can justify commercial sex workers?

\section{Method}

\section{A. Research Types and Approaches \\ 1. Research Types and Approaches}

The research approach method used in this study is a qualitative empirical approach, namely in this research and writing by explaining and describing phenomena that are then analyzed both normatively and socially. Utilization of this method approach according to researchers in accordance with the object under study, not using numerical data will still use qualitative data to make observations which means to see the phenomena that occur at the study site and get deata with interviews that is qualitatively.

\section{Types and Sources of Data}

The research has sources of data which will support the results of the research conducted. The data source is very important because with the data source, the research / report carried out will produce maximum results and the data presented is not wrong data but reliable data on empirical data in accordance with the facts in the field. Data sources used are:

\section{1) Primary Data}

Primary data sources are data obtained from the source, observed and recorded for the first time. Data collection is done during observation that is focused on the object of direct research that is on the resource persons directly related to the research conducted (Syatori \& Gozali, 2012). This primary data collection uses the method of direct interviews so that the primary data obtained is in accordance with the reality in the research location.

\section{2) Secondary Data}

Secondary data is data obtained from other parties such as scientific journals, or secondary references in addition to clarifying research on this issue (Marzuki, 2002; Arifin, Waspiah, \& Latifiani, 2018). Secondary data conducted in this research is looking for additional data sources other than the culprit, residents around the location of the study site both local residents or online motorcycle taxi and references from books and journals that are 
normative in order to support the primary data that has been presented, but for get this secondary data must be able to compare with the primary data that has been obtained if the relevant competing data and support is entered and that is not suitable to be replaced with another, so secondary data is not merely used directly but must be considered first.

\section{B. Data Collection Method}

Data collection methods are the most important thing in conducting research because using data collection techniques will obtain data that can be trusted authenticity, in conducting this research the data collection techniques used are:

\section{1) Observation}

Observation is a systematic observation and recording of the phenomena under study. Of the various observational methods that can be carried out, this study uses field observations which means that direct research is carried out around the research location, namely by coming to an angkringan or place to eat to make direct observations observing what happens in the vicinity of the research location.

\section{2) Interview}

Interview is the process of obtaining activities for research purposes by means of question and answer, face to face between the interviewees or the interviewer with the answerer or respondent by prioritizing a tool called a guide. The interview used by structured interview researchers is that the researcher prepares in advance by preparing questions relating to the perpetrators, so that the questions given are structured and have clear guidelines. Interview guidelines that are clearly used from the formulation of the problem are still in further detail so that the results of the research conducted produce data in accordance with the facts, this interview is addressed to Mr Bambang as an online motorcycle taxi located in the vicinity of the research location and our main resource person is Mawar as a commercial sex worker. The tool used during the interview is to use a digital camera to record video and sound.

\section{Research Location}

The location of our research is around Pocol Station precisely along Jalan Imam Bonjol Semarang and Jalan Tanjung close to Poncol Station. The location of the study that we were aiming at was many CSWs who were hanging out and we got the CSW resource persons who were on Jalan Tanjung.
1) Along the road in front of the Poncol station to the old city powder

2) Angkringan of local residents

3) Hotels to serve the customers

4) Roadside around the poncol

\section{Research Schedule}

Table 1. Schedule of Research

\begin{tabular}{lll}
\hline \multicolumn{1}{c}{ Date } & Time & \multicolumn{1}{c}{ Activity } \\
\hline $\begin{array}{l}\text { Wednesday, } \\
\text { 10 April }\end{array}$ & $22.00-$ & $\begin{array}{l}\text { Identifying the surrounding } \\
\text { environment, seeking } \\
\text { information through local } \\
\text { residents, looking for } \\
\text { informants related to the } \\
\text { party, looking for the target } \\
\text { group }\end{array}$ \\
\hline $\begin{array}{l}\text { Sunday, 28 } \\
\text { April 2019 }\end{array}$ & $21.00-$ & $\begin{array}{l}\text { Identify the types of } \\
\text { sex workers and the hours } \\
\text { of attendance }\end{array}$ \\
\end{tabular}

\begin{tabular}{lll}
\hline $\begin{array}{l}\text { Monday, 29 } \\
\text { April 2019 }\end{array}$ & $\begin{array}{l}20.00- \\
24.00\end{array}$ & $\begin{array}{l}\text { Interview with the PKK } \\
\text { who has agreed to conduct } \\
\text { an interview first }\end{array}$ \\
\hline
\end{tabular}

\section{Explanation}

Wednesday, April 10th was the first time we conducted an investigation of our object, Commercial Sex Workers (CSWs), we began by identifying the environment of PSK itself, which is along the Poncol station road to the direction of the road to the old city, not only that we also mingle with the public in the latest information and also you learn to find the target to distinguish the person turns out to be a sissy or not that we need to know too of course. On that first day we also did a team division to identify those who were mingling and those around to see the environment. Our initial plan was to only want to see the conditions in the field in preparation for our next observation. We got speakers from the online motorcycle taxi and the seller there. When we dig up information through informants we get direction and right away we look for our research object so that we can get an object that is CSW.

Sunday, April 28. On this date is the second time we conduct research on an area that is famous for being an area in the city of Semarang which has nightlife in the city of Semarang itself. The plan we will do on the second day is an interview with the informant namely PSK but it is predicted that on that day the weather did not support because it was raining and on Sunday it turned out that our informant was not in place so our plan at the beginning to interview failed. Therefore we carry out the transfer of plans by continuing our 
identification in the surroundings of the location. When doing the field research, we get a phenomenon that on the first day we have not gotten there is a way of accounting and delivery of prostitutes to mamgkal. After getting a new identification we decided to return home.

Monday, April 29. On the third day, we used it maximally to interview the prostitutes who were willing to be interviewed by us, we conducted the interview in the hotel room. But we as students will still not like that. Before conducting the interview, we had an agreement with the resource person that there was a rent to pay because the informant said that he had taken up his working hours, so we decided to pay for the smooth running of our duties. Initially our plan involved interviewing all, but from the interviewees it only asked for a maximum of two people, so we divided the assignment into interviews and others identified the exact environment around the characteristics of CSWs in the locations around the study.

\section{Result and Discussion}

\section{A. Overview of Criminology}

Criminology is the science of law aiding criminal law to provide an understanding of crime, because the perpetration of crime and efforts to tackle crime, aims to minimize the rate of development of crime. Criminology comes from the Latin crimen and Greek-logia, etymologically, criminal comes from the word crime and logos, crime means crime and logos is knowledge, so logos can be interpreted as criminology is a science that is related to crime. demonstrate scientific knowledge about the nature, extent, causes, and control of criminal behavior both within individuals and in social, cultural, political and economic life.

According to W.A. Border criminology as a scientist who has the authority to investigate the symptoms of crime as widely as possible (critical criminology and pure criminology). Theoretical criminology is experience-based science, which, like other similar sciences, pays attention to symptoms and tries to investigate the causes of the crime, etymology (Utari, 2012). Criminology is a scientific tool for the study of crime and criminals. In this form of science, criminology is "the body of knowledge" the scope of the crime is a) the person who commits crime b) the cause of the crime c) prevents the crime of d) ways to cure the person who has committed the crime.

Criminology formulation according to Wolf Gang Savitr and Jhonston is: "Criminology is the science that uses scientific methods in studying and analyzing orderliness, uniformity, patterns and causal factors related to crime and criminals and social reactions to both" (Simanjuntak, 1981) .

Criminology is a discipline to study crime, basically it depends on other disciplines that study crime, Criminology is a collection of various disciplines that study crime. So criminology is "interdisciplinary" meaning that the discipline is not independent but rather from the results of other studies of crime. This approach is the approach of various sciences to the same object, namely crime. Criminology with its scope examines:

a) People who commit crime.

b) The cause of committing a crime.

c) Prevent crime.

d) Ways to heal those who have committed a crime.

\section{B. Overview of Prostitution \\ 1. Definition of Prostitution}

Prostitution in estimology in Latin that is "pro-stituere" means allowing oneself to commit adultery, conduct prostitution and repeal. Whereas the word 'prostitute' refers to the word TunaSusila (WTS), which means a wretched person or a matter of selling themselves as work is surrendering or selling services to the public to perform sexual acts by getting rewards in accordance with what was promised previously. In practice, an actor wants this because there is a desire to get a reward. Someone who does the work can be said as a Commercial Sex Worker (CSW). Prostitution or prostitution is the practice of relations done for a moment, carried out with anyone to get rewards in the form of money.

HMK Bakry declared prostitution as strong as adultery. Prostiusi is a woman who surrenders her body to a man for swimming and receives the stipulated reward. Dr. H. Ali Akbar also proposed a restriction, that prostitution was an act of adultery, because it was outside a legal marriage (Ashari, 1986).

Three main elements in the practice of prostitution, as explained by Anwar \& Adang (2008), are:

a. Payment, this is done after an agreement between the perpetrator and the customer, in 
return for an action that has been done, namely the fulfillment of satisfaction by the perpetrator.

b. Promiskuitas is the practice of doing free sex by anyone often with a different partner by not choosing whoever the partner is invited to without any binding rules

c. Emotional indifference, customer relationship and no relationship whatsoever any relationship is limited to the customer to satisfy his lust, without the feelings carried by each other, because the psk is just looking for reward.

d. Livelihood. While certain groups view prostitution as a woman who is immoral, cannot stand the faith and as an anti-starch attitude towards prostitutes who for various reasons enter the dark world without regard to the connection with various aspects of community life that have a relationship with prostitution.

According to Kartono, prostitution or what is often referred to as prostitution is prostitution or what is often called prostitution is satisfying sexual desires, this is the oldest work of humans themselves (Bagong, 2012). Surely this is a hereditary problem in society because everyone's social life is different and the factors are different.

\section{Legal Basis of Prostitution}

With regard to prostitution, the Criminal Code regulates it in two articles, namely Article 296 and Article 506. The Criminal Code makes a deliberate act of causing or facilitating acts of violating the decency with a third person as a livelihood or as a habit set out in article 296 which reads: "Anyone who intentionally causes or facilitates obscene acts by others, and makes them livelihood or habit, is threatened with a maximum imprisonment of one year and four months or a maximum fine of fifteen thousand rupiah" (Hamzah, 2008).

Article 506 of the Criminal Code is regulated regarding criminal acts as pimps or pimps who take advantage of acts that violate decency and profit from acts that violate the morality which is attributed by a woman or man, which reads: "Anyone who withdraws the profits from the obscene acts of a woman and makes them a prostitute, is threatened with a maximum imprisonment of one year" (Hamzah, 2008).

\section{How to do Prostitution}

Prostitution activities are determined by someone with the modus operandi in WTS in carrying out their activities. Some stand alongside the road, sit in city parks, some do it in bars, some wait for phone calls, some occupy certain locations as practice prostitution, there are also those who do it under the guise of a massage or karaoke parlors. These various ways they offer a variety of sexual services, and therefore can be classified as several activities, ranging from ways, with this classification so it makes it easy to foster prostitution both mentally and spiritually, such as health care, the system of each classification is different with various motives, places, customers.

\section{Street Prostitution}

Prostitution which includes this street is often referred to as prostitution or streetwalker prostitution. This type is commonly found in big cities in the provincial capital in Indonesia. The WTS at this activity often stood waiting for men or guests at a certain roadside, especially at night around 21:00 - 05.00 in the morning. Usually these prostitutes can easily be identified by our behavior that they can show. These prostitutes are usually easily found in dim places while waiting for a man or his date, they have the courage to not hesitate to tease the men who pass in front of him, or give signs such as waving, winking and other movements that can provide attention to men. In general, services provided by this type of prostitution are provided to men or low-income customers, for example laborers, motorcycle taxi drivers, drivers and other small traders. This is due to low sexual service tariffs and affordable for those on low incomes.

If viewed from an economic perspective, the perpetrators of prostitution can be said to be a weak economic group and to fulfill their daily needs they are willing to provide sexual services to men who need them. Therefore, the impact of this prostitution is health, due to frequent changes in partners and do not know that each customer has a disease or not, but it can also be caused by rarely checking his health, especially the genitals. In street prostitution this is not tied to pimps or pimps, they do it on their own basis and the rewards they receive themselves are without anyone else's. But there are also those who share the benefits to protect and protect them from acts of customer violence or non-payment.

\section{Prostitution Calls}

Prostitution like this can be said as a Call Girl, in prostitution is carried out with the presence of other parties such as intermediaries called pimps, so that the prostitution is controlled by pimps. One of 
the underlying characteristics of this type is that prostitution is not done in the same place, but a place that always changes according to the agreement of both parties, usually done in hotels, recreation areas or mountains. When compared with call prostitution, the bargaining power of prostitution is higher at a cost of hundreds for short time. The income from the results is divided by pimps.

\section{Prostitution of a brothel}

This prostitution as a practice of prostitution, where its existence can be found in certain places, in the form of houses called brothels, where every brothel has guards as pimps as intermediaries. In this type there are social factors because it provides employment to various parties around the environment, including selling food, laundry, drug dealers, hotels.

\section{Covert Prostitution}

This prostitution is on the street with illegal covertness, which is also biased through pimps or pimps, usually this type of prostitution can be found under the guise of a spa salon, or the internet. They do not work alone, but there are various parties that protect their activities.

\section{Types of Prostitution}

a. Prostitution activities are divided into two types, namely:

\section{1) Registered prostitution}

In general, they are localized in a certain area, have a legality in place, namely localization, the government has a role in this regard, namely in the field of health and safety, residents must periodically check themselves with doctors or health workers, checking in the form of HIV / AIDS and the health authorities provide contraception every examiner. The perpetrators are supervised by the police in collaboration with the social and health services,

2) Prostitution that is not registered is not a localization.

They carry out prostitution in a dark and dark. Both individually and in groups. The deeds are not organized and the place is not certain, it can be in a place, either looking for prey alone or through brokers and vocations. They do not register themselves with the authorities. So. the crime is very doubtful. b. According to the amount of prostitution is divided into 2 types, namely:

1) Prostitution that operate individually can be called a single operator or street prostitute.

They usually hang out on the edge of city streets, stations or places that are considered safe. These prostitutes carry out their profession in disguise.

2) Prostitution which works is arranged in collaboration with the help of organized and neat syndicates and organizations.

They do not work alone but are regulated through an organizational work system. Usually in the form of border houses, bars, casinos.

c. According to the classification or localization:

1) Isolated segregation or localization, isolated by the residence of the population. As is the case with localization in Sillir Solo and Gang Dolly in Surabaya. These are what later become prostitutes on the streets in cooperation with pedicab drivers and traders.

2) Calling at home, this has a special characteristic where only the related parties know, without the presence of other parties so that the activities are more closed and organized.

3) There is abuse behind the front of a respectable organization or business such as (beauty salon, massage salon, restaurant, internet cafe, karaoke place, etc.). Here there has been a good organization that involved security people such as the police.

\section{Types of Prostitute}

Reekless distinguishes prostitutes for eight types as quoted by Ayu (2011), which is as follows:

1) Professional Prostitute is that they do prostitution as the main income because they do not have other jobs, the habit that is carried out is sexual relations with other people as a habit to make money or simply to gain profit.

2) Occasional Prostitutes, those who have certain jobs, but at any time use the opportunity for prostitution

3) One-man Prostitute is those who sell themselves to a certain person and behave as a pet to get benefits and money.

4) Promicious adulteress, are those who have a husband but have relationships with others.

5) Adulteress with one man, adultery committed with someone, even if he himself has a husband, but having a secret relationship and not solely for the needs of money and profits. 
6) Promiscuous unaltached, those who are not married or those who have become widows, or those who are separated from their husbands, or divorced, have sexual relations with several people without taking advantage.

7) Unconvensinal, are women who enter an unofficial household and act as husband and wife, or those who have sexual relations before a legal marriage.

8) Doubtful, women who are doubtful whether prostitutes or adultery

\section{Results of Interviews with CSWs}

The interviewee we named was Ibu Lily, who we disguised her name as a PSK (Commercial Sex Employee) on the Jalan Imam Bonjol Semarang around Poncol Station, she was 34 years old, living in Semarang, having 2 children aged 16 years and 7 years, at first Ibu lily works as a karaoke guide in Galpanas Karangjati, but behind the work there are irregularities such as free sex and alcohol every day, she thinks if this is done until old age it will have an impact on her health and therefore move to prostitution in poncol.

From the work, there are several factors and background underlying lily's mother to work as a prostitute, namely the economic crush because she is a widow who has divorced from her summers so that she has the financial burden of the needs of the child who is borne alone to support her family, lily's mother also does not have a job and lack of skills and education even though he did not graduate from junior high school, this is what forced Lily's mother to become a prostitute.CSWs

located around Poncol station on the Imam Bonjol road, have different physical characteristics of CSWs in other brothels, from clothes already seen usually wearing minimal clothing, but there are also those wearing modestly covered clothes, but if we see someone hanging around road or on a motorcycle without doing any activity then we can guess as CSW.

To follow up on irregularities in the community, the government took actions through the municipal police officers who raided prostitutes along the Imam Bonjol road. If the prostitute was caught once, rehabilitation measures were carried out in Solo for three months. after leaving the sex workers there were given severance pay for businesses and cooking utensils such as magicom and dispensers. From the government's efforts, the rehabilitation measures did not change the situation and had a deterrent effect on CSWs, the CSWs were doing the same thing as making money by selling themselves.

In carrying out the work, the prostitutes do not have pimps, they work privately without any party to regulate, the prostitutes work carefully by not committing crime, if there are customers who do not pay, what will be done is to report to the local hotel security. The prostitutes are not tied to the place of subscription. Ibu lily only serves pelaggan who are in poncol and do not serve it online or elsewhere through whatsapp, every night lily mother works from 21.00 to $05.00 \mathrm{am}$, from there getting customers between 3-5 with a cost per person Rp. 150,000 includes room Rp.30,000 and contraception but there are also customers who bid up to Rp.100,000, the price here is adjusted based on the agreement between the prostitute and the customer.

Technical in conducting transactions, So lily's mother sat along the way of Imam Bonjol, after that there will be customers who come to see Mrs. Lily to talk about prices, places and negotiations, after everything is agreed between the customer and the prostitute, the customer pays according to the agreement at the beginning paid to the prostitute and The prostitute handed over a sum of money to the hotel Rp.30,000 and took the spray bed that had been provided, after that they would go to the room and have intercourse, mother lily wanted every time she was obliged to use contraception this was done as an effort to avoid disease, the relationship done within the specified time that is 30 minutes, if the customer wants to add then pay according to the first agreement. According to information from Lily's mother, she has never been treated with violence or crime from customers, because she also chose pelaggan when in a state of severe intoxication would be refused to look after herself.

The government through the local puskesmas health service provides biweekly services in the form of blood tests and HIV/AIDS as well as getting one box of contraception free of charge. To get the service the CSWs must come to the local puskesmas, but there are also CSWs who do not use the facility for fear of positive results affected by the disease.

From the family, Lily did not know the work she did as a commercial sex worker. The child of Lily's mother did not know that she was a prostitute. privacy from the surrounding environment.

The impact that changed his life was a helped economy, he intended to stop being a prostitute for 
fear that if his family found out about his work then it would certainly be a moral burden and negative view of the surrounding environment, lily's mother intended if having capital would be used to open a business and send her child to school successful people. Lily's mother expects her child not to behave like her mother and expects to be a welleducated person.

\section{Characteristics of a CSW in Poncol Station Area}

Prostitution is a form of sexual deviations with impulsive or unintegrated patterns of impulse organization or sex drive in the form of impingement of sexual desires without control with many people (prosmicity), accompanied by exploitation and commercialization of impersonal sex without affection. Then Prostitution is an event of selling themselves (prostitution) by selling bodies, honor, and personality to many people to satisfy sexual desires in return in the form of payment. Prostitution can also be interpreted as an act carried out by a woman or a man who gives up his body to commit sexual acts in a sexual manner with the payment of wages.

From the point of view of prostitutes, prostitution may be analyzed more useful in terms of work rather than being seen as merely a free sex activity. This means that the exchange of money makes what he does ilaegal, and the exchange of money is why he does it. But from the customer's point of view, prostitution is usually about sex (sexually satisfying lust). More importantly, the public and the legislature view prostitution especially about sex outside the boundaries of marriage, aberrant sex, sex without the intention to reproduce, pay for sex (Lucas, 1995).

Prostitution and Prostitution are real forms of a moral deviation that lives and develops in the community. In its development, prostitution is difficult to separate from life in society. There are so many factors that cause and effect prostitution is growing day by day. Of legal norms that are not properly enforced or moral values that are increasingly eroded by the times. There are also other factors such as the opportunity to create a place to be a place for transactions related to prostitution or economic background that encourages someone to get involved in the world of prostitution. So it can be concluded that Prostitution is an attempt to trade sexual activities outside of marriage in exchange for material rewards. While prostitutes or what we can call CSWs (Commercial
Sex Workers) are defined as women or men who engage in sex outside of marriage in exchange for material rewards. Many ways to identify their members who play the role of running the world of prostitution.

Prostitution organs that can be identified by their characteristics in the world of prostitution are three, namely commercial sex workers, customers and pimps. CSWs are in fact those who are very active because they carry out the work according to their agreement with the customer or with their pimps. However, prostitutes can also work alone without pimping this they do by creating their own community. They can determine their own place, a comfortable place for them to work.

If they carry out the work individually without pimping, we can identify them with the habit of sitting on the side of the road while waiting for their customers to dress well and attract their customers, they are always patiently waiting without someone's supervision. As for the confession of a person we interviewed, in carrying out his work as a prostitute, he stated that there are two types of prostitutes, namely prostitutes who work alone or prostitutes who are sold by people or their own husbands. He stated that in the Poncol Station area there were no pimps who held prostitution. The characteristics of a prostitute working alone in the Poncol area are:

1. There is no supervision from thugs or the like

In carrying out the action, Poncol CSWs who work alone without influence from other people are found alongside the Imam Bonjol road near Poncol Station. They usually sit with friends or sit alone there are also those who bring motorcycles parked alongside the road.

2. Usually sitting on the side of the road or on a motorcycle

Those who work as Poncol prostitutes in selling themselves, the way they do is by sitting on the side of the road by offering their smiles so that those who intend to look for CSWs are interested in it.

3. Dressing normally, sexy and conspicuous In carrying out their work, the Poncol CSWs in wearing clothes are indeed varied, some who use plain clothes or conspicuous sexy clothes. This is sometimes rather difficult to determine which CSWs are and where residents around who are having needs outside the home. 
4. Dress up strikingly

To attract customers, CSW Poncol are competing to make up themselves to attract customers.

Whereas the characteristics of commercial sex workers sold by pimps, thugs, or their husbands are:

1. There is supervision from the pimp or from the husband who sells it

Whether or not there is supervision from someone, it can be seen from around the PSK Poncol that is hanging. The supervisors of the CSW are usually the husbands or thugs around, the hoodlums or the PSK husbands watch by sitting or hanging out near the Poncol CSW.

2. Sitting on the edge of the road or on a motorcycle or localization

Like other sex workers, sitting on the side of the road or waiting on a motorbike is one way for them to choose their existence in finding customers.

3. Dress sexy and flashy

In carrying out their work, the Poncol CSWs in wearing clothes are indeed varied, some who use plain clothes or conspicuous sexy clothes. This is sometimes rather difficult to determine which CSWs are and where residents around who are having needs outside the home.

4. Dress up menor

To attract customers, PSK Poncol are competing to make up themselves to attract customers.

Identification of the characteristics of CSWs who work alone with CSWs that are sold is the first subject. Then, the CSW we interviewed is an example of a CSW who works alone because he is forced by his economic situation, he becomes the backbone of the family especially in meeting the necessities of life because he does not have a husband. He also revealed how to distinguish the characteristics of female prostitutes with the characteristics of transvestite prostitutes in Poncol.

The characteristics of transvestite sex workers are:

1. In terms of appearance looks like a woman but somewhat like a man

This physical characteristic makes it possible for customers to identify whether it is a woman or a transsexual, transsexuals declare themselves to be homosexual, so they serve men who want to with them.

2. In terms of face looks like a man

Indeed, however, men dressed up as female adolescents look like men, especially the transvestites who become CSWs in Poncol are mostly middle-income and below. They don't have enough money to operate to perfect their desire to be a woman.

3. From the sound is a bit rough like men

We can get these characteristics when we interact directly by inviting them to chat, because when they talk that they often slip up with the male voices they say.

4. Has a feminine nature

To maximize their character to become a prostitute, they also changed their attitudes from masculine to feminine. This they do to perfect their character in carrying out work as a homosexual prostitute.

Such characteristics will distinguish Poncol CSWs from one another. Kartini Kartono also explained about the special characteristics for CSWs. The characteristics of the CSWs delivered by Kartini Kartono:

a. Female, the opposite sex is a gigolo (prostitutes, men, male prostitutes).

b. Beautiful, beautiful, beautiful, sweet, attractive attractive, both face and body. Can stimulate male sex appetite.

c. Still young. $75 \%$ of the total number of cities is 30 years. The most is $17-25$ years. Low and middle-class prostitution often employ prepubescent girls aged 11-15, which are offered as new goods.

d. Very flashy clothes, colorful, often strange or eccentric to attract the attention of men. They are very concerned about their outward appearance, namely: face, hair, clothes, cosmetics and stimulating perfume.

e. Using sexual techniques that are mechanical, fast, not present psychologically (afwejig, absent minded), without emotion or affection, can never achieve provocative orgasms in coitus, and are usually done roughly.

f. Are very mobile, often move from one place or city to another place or city.

g. Professional prostitutes from the middle class mostly come from economic start and low social start, while prostitutes from high class (high class prostitutes) are generally educated in junior and senior high school, or academic 
and college graduations, who operate amateur or professionally.

h. $60-80 \%$ of these CSWs have normal intellect. Less than 5\% are those who have weak memories (feeble minded). The rest are those who are on the boundaries, who do not determine or are not clear in their intelligence degrees.

Kartini Kartono (1981) explains that since human existence, prostitution has existed, and will continue to exist as long as human life still exists. This is based on the assumption that instinctively, humans both as individual creatures and as social creatures, through various means and efforts in the form of culture, have the will, among others:

1. Defend himself from the existing disturbances and challenges.

2. Maintaining life and developing life.

3. Maintain the life of his generation through marriage.

4. Holding sexual relations between the two sexes to meet the biological, and others.

Then seen from its development, there are differences between CSWs from one another as explained by Indarto (2015), namely:

1. Street Walker, which is a type of commercial sex workers who directly look for and find their customers, he is more in a public place, on the highway or the terminal. As a result of their activities in public places, they are often the subject of PP satpo's activities. The rates they put are cheap and in conducting transactions they can do it directly at the place where customers and CSW meet.

2. Bar Girl, which is a type of commercial sex workers that is usually done in an open place for those looking for and transacting with customers, in an open place but in a closed scope. Often the transaction system can be done through brokers or pimps (pimps), but not all is done through intermediaries they can do it themselves.

3. Call Gril, which is the most private type of CSW, generally the meetings and technical transactions they take place at an agreed place. CSWs who do this work are difficult to identify because of their private nature.

4. Other sex work, which in the subject is mostly done by teenage children where they do on the basis of like and like not to be paid.

The customer is an important subject of an act of prostitution. Customers who pay for sex workers are usually only looking for sexual satisfaction, they will never be satisfied. Prostitution states that it is a place of escape for single men or those who have greedy sexual appetites (Walor-Sagura, Exposito, \& Moya, 2011). In our observations, we can identify how customers who are looking for CSWs in the Poncol Station area. The characteristics of someone who is looking for CSW are:

1. Bring a motorcycle

Most CSWs Poncol customers bring motorbikes because this will make it easier for them to get to the place they are going to after the agreement.

2. Wear clothes that are neat, jacketed and helmeted

Wearing neat clothes and jacket are used to disguise themselves so as not to get caught by the closest people because most customers buy prostitutes because they are dizzy with the situation or because there are problems in their household or just looking for sexual satisfaction.

3. In choosing prostitutes they walked up and down along the Poncol Station road

Lots of CSWs in Poncol Station, whose working hours fail at the length of the Ponco Station road. Customers will walk here and there to choose which CSWs is suitable for him.

\section{E. Background Someone Becomes CSWs}

CSWs are one of the many problems that have arisen among Indonesian people. Being a prostitute is clear that it violates the norms prevailing in society, and violates the religious norms. In addition to violating the norms of the norm also contradicts the laws and regulations, but there is no rule that can protect from not doing the work. Sociologically CSWs are acts that are contrary to social norms, values that apply in society. This behavior often occurs because the community has ignored the norms, values that apply so that the behavior gives a negative assessment on a prostitute.

In general, someone who enters into the world of prostitutes is caused by a lack of life, through invitations from friends, disharmony within a family, and indeed finding out for themselves about CSWs. In the life of globalization to get a job is not easy to return both hands. Getting a job must also be supported by a skill, education, and an experience at work. The needs of globalization are now most needed, namely working to get money to 
meet their daily needs. According to the results of observations that have been made factors that influence someone to become a prostitute are:

1. Economic Factors

The dominant factor behind the foray into the world of sex workers is the lack of an economy, the difficulty of finding a job without the support of education or skills so it is difficult to find decent work. Therefore, in order to get an income for everyday needs, someone chooses easy work and does not require complicated requirements. Therefore, someone chooses to become a prostitute because it is easy to do. Like Lily's mother, she chose to become a prostitute because she had to fulfill the needs of her two children because she had divorced her husband, which caused her to be able to fulfill the life of her child, and Lily's mother did not have the ability, proficiency in work, and low education even junior high school did not graduate

2. The Difficulty Factor of Finding a Job

The next factor is the difficulty of finding work, the intended work is decent work or work that does not conflict with the rules, rules, norms that apply in society. The ability to get decent jobs is the main thing that is able to compete with others to get a job supported by the ability, skills, expertise in a field or other fields. However, getting a decent job is not easy to have to have high interest and competitiveness. These things are difficult to do, therefore the community prefers easy work and gets a decent income and is able to meet their daily needs. And the uneven development of employment opportunities for the community is still minimal. Therefore, the community prefers to become a prostitute because they have just broken up to look for a job, as experienced by Lily's mother who does not have proficiency in employment plus she is a widow who must meet the needs of her two children, so she must do to become a Even though the prostitute knows that the work is contrary to the norm, the rules in the community and lying to his child, his work is to be found in a place where he eats like a penyetan.

3. Factors of Low Education Level

Education is the most important thing in a person's ability to compete with others. Education is also a transformation, inheritance, and values that are in society. The role of education is very important because as it develops, advancing development in the community automatically issues that arise and appear are new problems and must be faced with educational abilities. It is said that someone who has a high education will bring a fortune to himself and someone who has low education plus does not have special abilities it will be difficult to compete with others. Similar to being a prostitute, he had given up hope in the field of education because it was principled that high schools needed high costs. Like Lily's mother, she even graduated from junior high school and was not equipped with special abilities, so she prefers to become a CSW whose work is easy and uncomplicated and able to fulfill her family's daily life.

4. Income factors become more adequate CSW

The choice of working to become a commercial sex worker also has a consideration in his income, even the prostituted income is able to exceed the adequacy of daily life. In terms of morals and instincts a prostitute also needs food and daily needs. One last resort is to make his body as capital to get money, but it is becoming more and more common place so he prefers to become a prostitute rather than looking for other jobs, the aim is also the same to fulfill his daily needs. Ibu Lily, a prostitute who also has a tariff, is also the result of observations that have been made to determine the tariff, usually the agreement between the prostitute and the customer. Ibu Lily has determined the price of the item is Rp. 150,000 including room loan of Rp. 30,000, sometimes there are also customers who bid Rp. 100,000, according to the agreement with the customer and get contraception when having sex.

\section{Family factors}

In addition to the factors above that cause a person to become a prostitute is a family factor. Against the background of the disharmony of a family, the demands to meet the needs of the family and others, our resource person, Ms. Lily, is also one of the factors, namely the family, because she has divorced her husband and she lives with her two children. Her children are only 14 and 7 years old, so Lily's mother must be willing to work to meet the family's needs as a demand from her family. However, Lily's mother hopes that her two children will not become like her, that is to become a prostitute and have to be highly educated. He also had the intention to become a prostitute, but was worried that he would not be able to pay for his two children's schools, and always lied to his two children that he did not work as a prostitute.

\section{F. Technical Ordering of Poncol CSWs}

Based on our research on CSWs in Poncol, we found many things there plus a lot of other things 
about the technical or procedures carried out to be able to get room service for the connoisseurs or seekers of services from sex workers. Regarding the mechanism contained in it, of course to be able to get room service, there are specific stages or ways that can be done can be online through social media or online booking or directly or offline booking. If you make an online booking a person who wants to enjoy the services of a prostitute usually has a relationship via social media to determine when to have a meeting and conduct sexual services, usually those who use online booking are those who have previously been comfortable with the services provided by prostitutes who he found that later made him his customer, in this way of booking, both parties must have made sure they would give and receive services while they were still in chat, but later after agreeing to meet, he would get it. From the answers of the CSWs that we meet say that they usually even have to be a little inconvenient because sometimes they only briefly provide services to consumers even though their body position is very tired. Usually the CSWs who can use the online booking system are young CSWs who are still in their 20 s because in our opinion there are also quite noticeable differences especially in the tastes of the CSWs themselves who can usually increase their passion in choosing and deciding which CSWs to choose. will accompany them.

The second method is the conventional way because it does not use the role of the media in attracting consumers from the services of CSWs. This method is usually used very easily where the searcher must find and choose which CSW he will use, based on the information of the CSW we interviewed, in Poncol area still uses the offline booking system, where CSWs usually hang out or peddle themselves on the roadside by staying quiet and teasing those who pass by either a car or motorcycle which after finding the choice of the prostitute, therefore they agree on the price that will later be accepted by the prostitute as service fees used in serving their sex consumers, after the price is agreed they will go directly to the hotel usually determined by the prostitute to be able to get these services.

However, those found in the area around Poncol itself prefer to use the offline booking system which can usually be found almost every night starting at 20.00 WIB which, usually we find very many PSKs that are on Jl. Imam Bonjol, there are many CSWs who have prepared themselves for later at a price (disawer), usually they are also on the motorbike while showing their spoiled attitude to everyone who passes there. We also get information that we can see that it is PSK or not based on their characteristics. Most of these offline booking systems are carried out by way of consumers' deal prices and when the meal is dealt, they will immediately go to a hotel room that has been provided by the prostitute. The information that we got was also derived from observations of local residents who also had one of the questions we asked about CSWs in the Poncol area. In addition, we also got information that in the region did not know pimps so that the CSWs in the Poncol area are selling themselves to consumers independently without any intermediary in them. So really from the PSK.

After that we also found information about the cost of PSK services to consumers. It turned out that the price was varied to millions, but according to information from our informants that the lowest price of CSWs was Rp. 120,000, - but as he said the last person there are still those who bid even to the lowest price up to Rp. 10,000; -. That price also does not include the cost of renting a hotel room that is used by CSWs with their customers later, for the price of renting a hotel room, we take the example of the hotel "XX" worth Rp.30,000, - for usage time for 30 minutes, for prices from other hotels too the same is not different because in Poncol itself hotel prices for CSW services are equated.

Not only about the technicalities but from the two booking systems that we explored, there are advantages and disadvantages that we can see directly. Of course, we find this information from our resource persons.

The advantages of online booking systems include:

1. It's easy and usually not difficult to make an appointment with a prostitute,

2. The prostitute immediately has a customer who will definitely come to him, without having to search on the side of the road,

3. Can add potential customers than the CSW itself because surely, there are certain people who also provide social media info that CSW who can order online.

4. CSWs can arrange their own time in serving their customers later.

Weaknesses of the online booking system include: 
1. Making a new veiled system for johns who want to get sexual gratification,

2. It could be that online ordering is a trap of people who really want to act evil to the prostitute,

3. Sometimes it is misused by parties who are not responsible for extortion or other evil things.

There is also the advantages and disadvantages of the offline booking system. The advantages of the offline booking system include:

1. The method used is relatively easy and fast and can avoid unwanted things

2. The prostitute can see directly about the prospective customer whether he thinks is appropriate or not for him to serve

3. No need to fear the abuse of social media contact that is owned by the CSW

The disadvantages of the offline booking system include:

1. Sometimes CSWs have to wait and search directly on the side of the road

2. Sometimes when the weather is not good and it does not support CSWs, it does not become open for sex

3. Fear of raids when they are looking for consumers on the side of the road

4. Sometimes there are also those who do evil to the prostitute, for example, even being kidnapped and thrown in another city after being served

\section{G. Criminological Theories that Justify CSWs}

Criminology or often referred to as crime is a phenomenon that often occurs among the community, be it a crime that has victims or not. One type of crime, namely prostitution or commercial sex work (CSWs), sometimes causes confusion that CSWs are criminals or victims of crime. When viewed from the perspective of criminology, a commercial sex worker is a perpetrator supported by evidence - including allowing themselves to commit adultery, selling sexual prosecutors (prostitutes), prostitutes surrendering, offering themselves and selling themselves. There is no coercion in the prostitute so it can be said that he has committed an act of crime, because it has violated moral values, moral values and is an act against the law. Criminology, there are theories that cause a person to commit a crime, according to the results of observations that have been done by a prostitute, there is also a connection with the theory of criminology. Criminological theories relating to CSWs of observations include:

\section{Differential Association Theory}

Crimes committed by someone because of the results of imitations or seeing acts of crime that continuously occur in the community, so that the impact on individuals to commit similar crimes (Dirdjosisworo, 2002). Before becoming a prostitute Lily's mother is our guest speaker working in a nightclub, she worked as a karauke guide in the Galpanas Karangjati area. Every day he was required to drink - drink every day he also saw sex activities freely carried out there. However, being a karauke guide there were demands to drink every day, he finally decided to become a prostitute, according to him the impact of old days was less dangerous compared to drinking.

If it is related to criminological theory, the emergence of crimes committed by Lily's mother is caused because she sees daily matters relating to sex, in her workplace such activities are common and every day she sees these activities, with the impact given is lighter than in becoming a karauke guide, then he prefers / imitates as commercial sex workers who according to him are more relaxed and more profitable in terms of income and health. Health as a prostitute in the Poncol station area is guaranteed, because every 2 weeks there is an examination on HIV / AIDS and free distribution of condoms for the health of the prostitute.

\section{Anomie's Theory}

Crimes that arise without the norms of society that causes social irregularities in the loss of stakes in the community, knowing the wrongdoing, but still committed because of certain factors (Atmasasmita, 2005). The crimes committed by Lily's mother belonged to the anomie criminology theory group because she knew the actions she did would have an impact on her family's self-esteem, therefore she was forced to lie for it all. She always kept it a secret from her family and the surrounding community, because it really needed a life necessity, Lily's mother had to keep doing her prostitute work, every night when she was asked by her son, he answered working in a place to eat like a penyetan. Lily's mother did this so that her child would not be disappointed and ashamed of his real work, because the act was deviant to the community, he knew his actions were not good, so he didn't dare to convey his true condition to his child. 


\section{Conflict Theory}

Conflict theory here is not conflict theory because there is a clash of culture or the like. The theory of conflict that causes a person must commit a crime because of the conflict experienced by each person - each. This conflict theory is also one of the factors in the emergence of a crime committed by someone. As experienced by Lily's mother, when she first became a CSW also because there was a conflict in her family, before becoming a widow, Lily's mother had a husband to make ends meet and her two children. However, due to an accident she divorced her husband, therefore Lily's mother had to be able to meet the needs of her two children.

Family conflict experienced by Lily's mother certainly has a great impact both in terms of economic, and psychological. If he wants to continue to meet the needs of his child, with the condition of Lily's mother, her education does not graduate from junior high school and does not have a skill, then the work she can do is to become a prostitute. Economic needs are the main factor because he needs money for the sake of his two children, the needs of their children's lives, food, shelter, and education. Lily's mother kept trying so that her son did not know the work he was doing and he hoped his two children would not be like him who became a prostitute but should be able to achieve higher education.

\section{Theory of Social Control}

Individuals in the community have a tendency to do good or not, it is influenced by environmental factors surrounding the community, behaving well or evil depending on the condition of the surrounding community. A person becomes good when his environment makes him a good person, and he will do evil if the environment around him makes him evil.

The theory of social control can be viewed as a theory that condemns the role of the surrounding community. The role of the most mediating community is someone who commits a crime or not. As experienced by Ms. Lily, before becoming a prostitute she became a karauke guide in the Galpanas Karangjati area. Every time he works in the environment around the karauke, on average he does a deviation which makes someone become evil, that is, the practice of prostitution, free sex, and drinking, eating it has an impact on Ms. Lily so that she commits similar acts of evil. because the environment around him made him work as a prostitute.

\section{Conclusion}

From our observations, it can be concluded that prostitution is a deviant act. Many factors behind a person can enter the world of prostitution. Family problems are usually what often happens, making someone despair and enter into this vicious circle. Prostitution is a place for seekers and lust satisfying their affairs. prostitution is seen as something that deviates by society, moral values increasingly eroded in it. Prostitution is also seen as a job, not merely satisfying sexual desire. In the world of prostitution, the work of CSWs is generally undertaken by women. A profession where a woman sells herself is contrary to the norms prevailing in the community. However, they do the profession because they have their own reasons. I don't think there will be women who have aspirations to become prostitutes. Many factors in life force them to fall into the world of prostitution.

One of them is the woman whose initials Lily we have interviewed, she revealed everything in Poncol Station related to this prostitution. He explained why he became a prostitute. The economic pressure he suffered was why, he worked as a prostitute to meet his daily needs. With work hours of 10 to dawn approx. He did not have a husband because there was a problem that happened to him, the necessities of life and the cost for his child made him confused what to do. Then, he took the road as a prostitute until now. His children do not know his mother as a prostitute, whose children know his mother goes to work. Lily said that in the Poncol Station area, it was not only female prostitutes who hung there, but also transsexuals. The harshness of life makes humans will undergo anything to fulfill what humans need. Run a woman who sells herself under the circumstances of Poncol Station, there are also transvestites and women who are sold by their own husbands or sell other people. It is sad when we see this, is this evidence of the inability of the state to overcome poverty. 


\section{Declaration of Conflicting Interests}

The authors state that there is no potential conflict of interest in the research, authorship, and/or publication/publication of this article

\section{Funding}

None

\section{References}

Akimov, Mykailo. 2018. Criminal Law Protection Of Person's Freedom: Problems And Solutions. "VISOUMENES SAUGUMAS IR VIESOJI TVARKA PUBLIC SECURITY AND PUBLIC ORDER" . Vol. 20 No. 5

Anwa, Yesmil Adang. Pembaharuan Hukum Pidana Reformasi Hukum Pidana. Jakarta: PT Grsindo.

Arifin, R., Waspiah, W., \& Latifiani, D. (2018). Penulisan Karya Ilmiah untuk Mahasiswa Hukum. Semarang: BPFH UNNES.

Atmasasmita, Romli. 2005. Teori dan Kapita Selekta Kriminologi. Bandung: Refika Aditama.

Bagong, Suyanto. 2012. Anak Perempuan Yang Dilacurkan, Korban Eksploitasi di Industri Seksual Komersial. Graha IImu, Jogjakarta.

Budyn-Kulik, Magdalena. 2018. Violence in Criminology- the Nature, Reasons and Perspective. "ANNALES Universitis Mariae Curie". Vol.LXV No.1

Dirdjosisworo, Soedjono. 2002. Sinopsos Kriminologi Indonesia. Bandung: Mandar Maju.

Dwi Kristian, Ni Made. Kejahatan Kekerasan Seksual (Perkosaan) Ditinjau Dari Perspektif Kriminologi . "Junal Magister Hukum Udayana". Vol 7 No. 32014

Edlund, L., \& Korn, E. 2002. A Theory of Prostitution. Jurnal of Political Economy. Vol. 110 No. 1.

Hamzah, Andi. 2008. KUHP dan KUHAP Edisi Revisi 2008. Rineka Cipta. Jakarta.
Imam, Asyari Sapari. 1986. Patologi Sosial. Surabaya: Usaha Nasional.

Indarto. 2015. Identifikasi Problematika Pelacuran Dalam Prespektif Hukum. Vol. 6 No. 4.

Jarvinen, M. 1993. Prostitution in Helsinki: A Disappearing Social Problem? Jurnal of the History Sexuality. Vol. 3 No. 4.

Kartono, Kartini. 1981, Patologi Sosial Jilid 1, Bandung. PT Raja Grafindo.

Lucas, Ann M. 1995. Race, Class, Gender and Deviancy: The Criminalization of Prostitution, Vol. 10 BERKELEY WOMEN'S L.J. 47.

Marzuki. 2002. Metodologi Riset. Yogyakarta: PT Prasetia Widya Pratama.

Matahari, Ratu. 2012. Studi Kualitatif Mengenai Persepsi dan Perilaku Seksual Wanita Pekerja Seks Komersial (PSK ) Dalam Upaya Pencegahan IMS di Kota Semarang Tahun 2012. Jurnal Kesehatan Reproduksi Vol. 3 No. 3 Desember 2012

Moeljatno. 2008. Kitab Undang-Undang Hukum Pidana. Jakarta: Bumi Akasara.

Norrie, Alan. 2017. Criminal Law and Ethics: Beyond Normative Assertion and its Crtique. "The Modern Law Review". Vol 80. No. 5

Rahmah, Hilda , Rina Iswari dan Kuncoro Bayu Prasetyo. 2016. Pemanfaatan Jaminan Sosial Kesehatan BPJS di Kalangan Wanita Pekerja Seks (Studi Pada Wanita Pekerja Seks di Sunan Kuning Semarang). "Solidarity". Vol. 5 No. 2

Sayatori, Toto dan Nanang Gozali. 2012. Metode Penelitian Kuantitatif. Bandung: Penerbit Pustaka Setia.

Senthilathiban, K, Modhava Soma Sundaram, R, Karunahidi, S., 1991. Reactions to Wife Neating; an Opinion Survey Among Students "Indian Journal of Criminology ". Vol 19 No. 1.

Sevgi O, Aral and Friends. 2003. The Social Organization of Commercial Sex Work in Moscow, Russia, "Sexually Transmitted Diseases". Vol. 30. No. 1. January 2003.

Simanjuntak, B. 1981. Pengantar Kriminologi dan Patologi social. Bandung: Tarsito.

Siregar, Kondar. 2015, Model Pengaturan Hukum Tentang Pencegahan Tindak Prostitusi 
Berbasis Masyarakat Adat Dalihan Na Tolu. Medan: Perdana Mitra Indonesia.

Siti Munawaroh. 2010. Pekerja Seks Komersial (PSK) di Wilayah Prambanan, Kabupaten Klaten Jawa Tengah. DIMENSIA. Volume 4. https://journal.uny.ac.id. 16 Mei 2019.
Utari, Indah Sri. 2012. Aliran dan Teori dalam kriminologi. Semarang: SatciptobRahardjo Institute.

Valor-Sagura, Inmaculada, Expósito, Francisca, dan Moya, Miguel. 2011. The Europen Journal of Psychology Applied to Legal Context, Eur. J: psychol appl legal context, Vol. 3 No. 2.

Submitted December 9, 2019

Revision received January 12, 2019

Accepted January 25, 2019

Published online February 3, 2020

\section{How to cite?}

Wicaksono, A.A, Saefudin, Y. R., Ramadhan, H., Pangestu, R. A., \& Arifin, R. (2020). Criminological Aspect on Case of Prostitution around Poncol Station Semarang. Law Research Review Quarterly, 6(1), 19-36. https://doi.org/10.15294/Irrq.v6i1.31099 
